\title{
Socialization Agents That Puerto Rican College Students Use to Make Financial Decisions
}

\author{
Enid Alvarez \\ Walden University \\ Steven Tippins \\ Walden University
}

\begin{abstract}
Using consumer socialization theory as theoretical framework, the purpose of this quantitative, nonexperimental, cross-sectional study was to identify the information sources that Puerto Ricans college students use to gather financial knowledge. A sample of 198 Puerto Rican college students answered a portion of the College Student Financial Literacy Survey. The research question addressed the preference of four financial information sources, including parents, peers, media, and school. A combination of descriptive statistics, one-way analysis of variance, repeated-measures analysis of variance, and multiple linear regression confirmed that participants preferred to gather financial knowledge from parents. Researchers, educators, and policymakers may use this study as a foundation for the development of effective financial education strategies that will promote positive social change in Puerto Rico.
\end{abstract}

Keywords: financial socialization, financial education, financial literacy, socialization agents, personal finance, finance education

\section{Introduction}

Financial literacy is an essential aspect of a healthy economy. After the financial crisis of 2007, the U.S. financial system became increasingly sophisticated (Lusardi, 2015). Every day, more citizens must take an active role in managing their finances as governments, banking institutions, and employers transferred the responsibility to save, invest, and plan for retirement to the people (Lusardi, 2015). Puerto Ricans, like many other U.S. citizens, must deal with these types of decisions daily. However, researchers suggested that many Puerto Ricans have low levels of financial literacy (Castro-Gonzalez, 2014; Martínez, 2013). Puerto Ricans have little knowledge about basic money management practices to help them make informed financial decisions. Researchers also agree that Puerto Ricans lack the financial knowledge and skills necessary to succeed in the new financial responsibilities they face, seeming unfamiliar with simple economic concepts (Castro-Gonzalez, 2014; González-Corzo, 2015; Martínez, 2013). This lack of knowledge has significant consequences for their financial wellbeing because it limits their ability to participate actively in the financial system.

Having adequate financial knowledge helps people make informed decisions regarding proper wealth management (Erner, Goedde-Menke, \& Oberste, 2016). Social norms dictate the attitudes, responsibilities, and beliefs that people should follow, including financial behavior. Likewise, socialization agents act as a transmitter of knowledge, norms, and motivations, hence modeling financial attitudes and behaviors (Gudmunson \& Danes, 2011; Moschis \& Churchill, 1978). Therefore, socialization agents play a significant role in fostering the financial beliefs of individuals and the decision-making processes that guide people's lives. 
Research addressing financial literacy and the socialization experiences of Puerto Ricans has been limited to a few studies. Most of the studies performed in Puerto Rico focused on participants' financial knowledge rather than the individual's knowledge-acquisition processes (González-Corzo, 2015; Gudmunson \& Danes, 2011; Martínez, 2013). As a result, there has been a lack of information regarding the sources that Puerto Ricans employ to gather financial knowledge. The purpose of this study is to examine the information sources that influence the financial knowledge and decisions of Puerto Rican college students. The present study extends the knowledge built by Fernandez (2002), Martínez (2013), and Castro-Gonzalez (2014) by identifying the information sources that Puerto Rican college students prefer to use to inform their financial decisions.

\section{Theoretical Framework and Literature Review}

The underlying framework of this study was based upon the consumer socialization model. Initially developed by Ward in 1974, consumer socialization explains the processes and the sources from which individuals obtain financial knowledge (Ahluwalia \& Sanan, 2016; Chu \& Sung, 2015). Moschis and Churchill suggested that parents, school, media, and peers act as socialization agents, transmitting consumer knowledge, skills, and attitudes. Socialization agents also transmit norms, attitudes, motivations, and behaviors to learners. Moschis and Churchill found that parents had the strongest impact as socialization agents, while school resulted as the weakest predictor. Meanwhile, mass media and peers played an essential role in developing consumerism attitudes in children and adolescents (Moschis \& Churchill, 1978). Finally, Moschis and Churchill found little evidence of a significant correlation between school or formal consumer education and consumer affairs knowledge. However, they suggested that additional factors may affect the impact of formal consumer education in the financial capabilities of people.

\section{Parents}

Parents represent the first socialization agent in the education process of children, acting as socialization agents in the primary stages of financial education (Dündar, 2017; Grohmann \& Menkhoff, 2015). Parents play a more substantial and stronger role on the consumer behaviors of children than other socialization agents (Chowa \& Despard, 2014; Dündar, 2017). Moreover, financial socialization experiences during early childhood are positively associated to financial asset ownership, higher household wealth, and safe investment ownership (Grohmann \& Menkhoff, 2015; Hira, Sabri, \& Loibl, 2013). People who experienced financial socialization during childhood exhibited stronger financial literacy skills and suffered lower levels of financial anxiety as adults. Also, these individuals would be more assertive in their financial decisions about savings, investments, and portfolio diversification.

\section{Peers}

Financial socialization experiences are not limited to the household. Children become engaged with socialization agents outside their family circle as they grow, including new friends and the lessons they receive from their teachers at school (Chu \& Sung, 2015; Dündar, 2017; Huston, 2015). Peers represent an important socialization agent for young consumers, having the greatest impact on purchasing practices (Moschis \& Churchill, 1978; Muralidharan \& Men, 2015). As the influence of peers becomes stronger during adolescence when the need for social acceptance increases, the role of parents becomes reduced. Becoming a grown-up provides no guarantee that people will become financially savvy during adulthood. As children reach adulthood, the need for social approval still exists, so they will keep relying on peers' feedback and opinions to make financial and consumer 
decisions (Delfino, Marengo, \& Ploner, 2016; Thaichon \& Quach, 2016). However, relying only on the recommendations from friends or peers without properly researching for information to make financial decisions might lead to disadvantageous outcomes.

\section{Media}

Individuals are also exposed to financial and consumer information through TV, newspapers, radio ads, and countless sources of information through social media. Researchers seemed to agree that media, in its different forms, plays an essential role in the financial socialization, consumer learning, and consumer activism of people (Ahluwalia \& Sanan, 2016; Moschis \& Churchill, 1978). Moschis and Churchill noticed a significant correlation between the amount of information obtained from mass media sources and social motivations for consumption and materialistic attitudes among children and adolescents. Moreover, researchers found that media as a socialization agent affects many purchase decisions through programming and advertising, considering it a predictor of consumer affairs knowledge among adolescents (Atkinson, Nelson \& Rademacher, 2015; Ahluwalia $\&$ Sanan, 2016). However, people also used the information they gathered from the media to make investment decisions. Hira et al. (2013) found that media had a strong relationship with investor involvement, positively influencing investment patterns, and acting as a strong predictor of saving behaviors.

\section{School}

Formal financial education represents one of the least assessed socialization agents in the literature, even though formal education increases both a person's knowledge and the ability to use that knowledge (Dündar, 2017; Huston, 2015). The influence of school on positive financial and consumer behaviors has been open to debate with only part of the finance research community linking financial education courses to improved financial practices. Grohmann, Kouwenberg, and Menkhoff (2015) determined that the influence of formal education positively affected the financial literacy and behavior of adults. Similarly, Shim, Serido, Tang, and Card (2015) argued that both formal and informal financial education played a significant role in the financial literacy of individuals. All these researchers agreed that students attending financial courses showed an increased understanding of diversification and exhibited less impulsive buying behaviors.

In contrast, many researchers found little evidence to prove the relation between financial education and positive behaviors such as investment, credit management, long-term asset accumulation, debt repayment, and financial health (Cole, Paulson, \& Shastry, 2016; Drever et al., 2015; Huston, 2015). Hensley (2015) encouraged further research to identify the best pedagogical practices to improve the success of financial education. Additional data would provide a better understanding of the most appropriate setting to implement specific pedagogical practices according to the needs of the target population. The researchers included in the literature also stressed the need to include practical experiences that combine different resources and tools to increase the impact of the education efforts. They argued that experiential learning resulting from active engagement with financial products provides benefits to financial wellbeing, giving students opportunities to employ the skills learned in the classroom in real-life situations. The impact of the practical experiences may provide students with a deeper and more comprehensive understanding of financial products and services, but also with learning that will last longer. 


\section{Methodology}

With this study, we sought to start a conversation about the social learning processes that influence the financial literacy of Puerto Ricans. So, the proposed study seeks to identify the sources of information or socialization agents that Puerto Rican college students use during their decisionmaking process. We also wanted to extend the knowledge built by Fernandez (2002), Martínez (2013), and Castro-Gonzalez (2014) about the social learning processes that Puerto Ricans experience. The intention of this study was also to generate data about the socialization practices behind the acquisition of financial knowledge among Puerto Ricans.

\section{Participants}

The student population attending higher education institutions in Puerto Rico reached 216,742 students in the fall of 2017 and was made up of $42 \%$ men and $58 \%$ women (Puerto Rico Council on Education, 2018). The population of the study was composed of Puerto Rican college students, 18 to 59 years old. A total of 255 participants answered at least parts of the College Student Financial Literacy Survey. Out of the 255 responses, 198 participants provided complete and viable responses to the survey, resulting in a $78 \%$ retention rate. Most study participants (88.9\%) were enrolled at a private university located in San Juan, and most participants in the sample of this study identified as male ( $n=141,71.2 \%)$. As shown in Table 1, the sample included students from both undergraduate $(n=174,87.9 \%)$ and graduate $(n=24,12.1 \%)$ levels and only $25.2 \%$ reported a family income of at least $\$ 50,000$ a year.

Table 1. Descriptive Characteristics of the Sample $(\mathrm{N}=198)$

\begin{tabular}{llrr}
\hline Variable & Category & $\boldsymbol{n}$ & \% \\
\hline Gender & Male & 141 & 71.2 \\
Age & Female & 57 & 28.8 \\
& $18-22$ & 124 & 62.6 \\
& $23-29$ & 53 & 26.8 \\
Academic status & $30-39$ & 12 & 6.1 \\
& $40-59$ & 9 & 4.5 \\
& College freshman & 30 & 15.2 \\
& College sophomore & 41 & 20.7 \\
& College junior & 57 & 28.8 \\
Income & College senior & 46 & 23.2 \\
& Master's student & 17 & 8.6 \\
& Doctoral student & 7 & 3.5 \\
& $\$ 0-34,999$ & 67 & 33.8 \\
& $\$ 35,000-49,999$ & 38 & 19.2 \\
& $\$ 50,000-79,999$ & 21 & 10.6 \\
& $\$ 80,000$ or more & 29 & 14.6 \\
& Don't know & 43 & 21.7 \\
\hline
\end{tabular}




\section{Research Design}

We used a cross-sectional design to examine the socialization agents that Puerto Rican college students prefer to use to inform their financial decisions. The independent variables of the study were parents, media (including the Internet), peers, and school. Financial literacy was the dependent variable of the study. The research question addressed was this: What sources of information do Puerto Rican college students use to obtain financial information?

Based on the previous research question, the study tested the following:

$H_{0}$ : The mean proportion of the sources of information used by Puerto Rican college students is the same for family, mass media, school, and peers.

$H_{\mathrm{a}}$ : The mean proportion of the sources of information used by Puerto Rican college students is not the same for family, mass media, school, and peers.

The purpose of the research question was to compare the means of the four socialization agents to determine the sources of information that Puerto Rican college students prefer to use when gathering financial information. The variable $\mu$ represented the mean scores of the responses collected from the survey for the four socialization agents (parents, school, peers, and media). The sources of information contained in the study included family or relatives; mass media, including social networks; money management courses; workshops; advisors; and peers, including friends, classmates, and coworkers.

A combination of descriptive statistics, mainly frequency and percentage, were used to show the score variations among the information sources. A one-way analysis of variance (ANOVA) provided the information to examine differences among the averages of the four socialization agents. Due to the nature of the data, a repeated-measures ANOVA was also used to compare the four sources of information and to assess further the research question. The multiple regression generated data to quantify the correlations between each predictor (parents, school, peers, and media) and the dependent variable (financial literacy).

\section{Results}

The research team examined the reliability of the College Student Financial Literacy Survey following the same approach used by Jorgensen in 2007. The reliability calculated equaled $\alpha=.56$ for the financial knowledge section of the survey using SPSS Version 24 (Questions 4-28). Reliability values over $\alpha=.70$ are frequently recommended (Field, 2013). However, many items on a subscale may include diverse themes (Field, 2013). In this case, the Financial Knowledge subscale of the College Student Financial Literacy Survey included topics about credit cards, investments, loans, and interest accrual, among other topics. The variety of topics might explain the low value obtained for Cronbach's alpha.

\section{Descriptive Statistics}

The data in Table 2 shows score variations among socialization agents. The data showed differences in scores, emphasizing the participants' preference for parents. It was found that the respondents sought out their parents more frequently $(n=142,71.7 \%)$ than any of the other information sources. Also, respondents sought out information from the media (52.5\%) more regularly than they used 
school (32.8\%) or peers (25.8\%) for the same purposes. Media, contrasting with data from the literature review, came in second place of preference among study participants.

Table 2. Sources of Information Sorted by Highest Frequency ( $\mathrm{N}=198)$

\begin{tabular}{lcccc}
\hline Source of Information & $\boldsymbol{n}$ & $\mathbf{\%}$ & $\boldsymbol{M}$ & $\boldsymbol{S D}$ \\
\hline Parents & 142 & 71.7 & 36.98 & 11.60 \\
Media & 104 & 52.5 & 39.74 & 13.27 \\
School & 65 & 32.8 & 39.82 & 11.57 \\
Peers & 51 & 25.8 & 39.00 & 12.51 \\
\hline
\end{tabular}

Note. Full one-way analysis of variance model: $F(3,361)=1.37, p=.25$.

\section{One-Way ANOVA}

The overall model was not significant ( $p=.25$ ), implying that there were no differences between the means of the four socialization agents. The results in Table 2 showed that the averages of the information sources range from 36.98 to 39.83. School $(M=39.82, S D=11.57)$ got the highest mean, which suggests that students that used formal education as an information source demonstrated higher levels of financial literacy. In contrast, parents produced the lowest scores $(M=36.98, S D=$ 11.60) among all four sources of information. This finding implies that parents are not as effective as other socialization agents to transmit financial knowledge.

\section{Repeated-Measures ANOVA}

The overall model was significant $(p=.001)$, suggesting that there were significant differences between the four sources of information. In general, the results of the test in Table 3 showed that the information sources used to gather financial knowledge affected the financial knowledge scores of participants. Bonferroni post hoc tests were used to compare the mean proportions for the four sources. Due to the ordinal nature of the variables, we also used a Friedman nonparametric repeated-measures test as an additional source of statistical verification. The Friedman test was also significant $(p=.001)$. This combination of findings provided support to reject the null hypothesis.

Table 3. Sources of Information Repeated Measures

\begin{tabular}{lccccc}
\hline Source & $\begin{array}{c}\text { Type III Sum of } \\
\text { Squares }\end{array}$ & $\boldsymbol{d f}$ & Mean Square & $\boldsymbol{F}$ & Sig. \\
\hline Information sources & & & & & \\
$\quad$ Sphericity assumed & 25.480 & 3 & 8.493 & 39.990 & .000 \\
Greenhouse-Geisser & 25.480 & 2.927 & 8.706 & 39.990 & .000 \\
$\quad$ Huynh-Feldt & 25.480 & 2.976 & 8.563 & 39.990 & .000 \\
$\quad$ Lower-bound & 25.480 & 1.000 & 25.480 & 39.990 & .000 \\
Error & & & & & \\
$\quad$ Sphericity assumed & 125.520 & 591 & .212 & & \\
$\quad$ Greenhouse-Geisser & 125.520 & 576.580 & .218 & & \\
$\quad$ Huynh-Feldt & 125.520 & 586.216 & .214 & & \\
Lower-bound & 125.520 & 197.000 & .637 & & \\
\hline
\end{tabular}

Note. Full analysis of variance model: $F(3,591)=39.99, p=.001$. Bonferroni post hoc tests: $1>2,3,4(p<.05)$; $2>3,4(p<.05)$; no other pairs were significantly different at the $p<.05$ level. Friedman nonparametric repeated-measures test $\left(\chi^{2}=100.23, p=.001\right)$. 


\section{Multiple Linear Regression}

As an additional related analysis, Table 4 displays the results of the multiple regression model predicting financial literacy based on the four sources of information. The overall model was significant $(p=.003)$ and accounted for $7.9 \%$ of the variance in financial literacy. Inspection of the beta weights suggested that financial literacy was higher when respondents received information from school $(B=.14, p=.05)$ and from media sources $(B=.22, p=.003)$. Although $71.7 \%$ of the sample sought their parents more frequently, participants that reported getting financial information from school (32.8\%) got higher scores in the financial knowledge component of the survey. These students demonstrated being financially smarter than the rest of the sample who got financial knowledge from other sources of information.

Table 4. Multiple Regression Model Predicting Financial Literacy Based on Sources of Information $(N=198)$

\begin{tabular}{lccccc}
\hline Source of Information & $\boldsymbol{B}$ & $\boldsymbol{S E}$ & $\boldsymbol{\beta}$ & $\boldsymbol{p}$ & VIF \\
\hline Intercept & 35.02 & 2.11 & & .001 & \\
Parents & 0.52 & 1.98 & .02 & .79 & 1.02 \\
Peers & 1.77 & 2.04 & .06 & .39 & 1.02 \\
School & 3.77 & 1.89 & .14 & .05 & 1.01 \\
Media & 5.51 & 1.81 & .22 & .003 & 1.05 \\
\hline
\end{tabular}

Note. VIF = variance inflation factor. Full model: $F(4,193)=4.15, p=.003, R^{2}=.079$. Durbin-Watson $=1.73$.

There were five assumptions used to assess the accuracy of the statistical tests: (a) normality, (b) homogeneity/homoscedasticity of variance, (c) independence of errors, (d) multicollinearity, and

(e) sphericity. We used a series of graphs and statistics to perform these tests, including histograms and P-P plots of the collected data to examine the normality of the data collected. The histograms showed normally distributed scores for the data. P-P plots confirmed that the data points showed no signs of kurtosis or skewness in the data, suggesting a normal distribution of errors. The scatterplots of standardized residuals against standardized predicted values for the financial knowledge scores showed that the data did not funnel in any direction, demonstrating that there was no systematic relationship between the errors in the model. The Durbin-Watson statistic (1.73) located at the end of Table 4 shows that the independence of errors in the data is tenable and demonstrated the independence of errors in the test. Table 4 also provided data to assess the multicollinearity of the data used to answer the research question. The variance inflation factor shows that all the variance inflation factor values are close to 1, and none exceeded 10, as suggested by Field (2013).

\section{Discussion}

In general, Puerto Rican college students lacked financial knowledge, which agrees with the findings included in the literature review. The sample averaged a mean of $39.97 \%$ score in the financial knowledge component, a score below the 49\% found by Martínez in 2013. When taking a detailed look, we found that participants know most about factors for loan approval (Question 10, $n=179$, 90.4\%), followed by cosigning a loan (Question 11, $n=154,77.8 \%$ ), and leased apartment but never occupied it (Question 9, $n=141,71.2 \%$ ). In contrast, study participants knew the least about the responsibilities of a stolen credit card (Question 15, $n=9$, 4.5\%), investments for retirement 
(Question 8, $n=35,17.7 \%$ ), and interest charges on new credit purchases (Question 16, $n=36$, 18.2\%). Table 3 shows additional information about individual financial literacy item answers.

The statistical analysis of this study emphasized existing significant differences between the information sources included in the study. The results of the survey demonstrated that respondents in the sample significantly favored parental socialization because $71.7 \%$ of the sample identified parents as their preferred source of financial information. This result concurred with many financial researchers who argued that parents play a stronger, more significant role in the development of financial behaviors than any other source of information (Bucciol \& Veronesi, 2014; Chowa \& Despard, 2014; Drever et al., 2015; Dündar, 2017; Grohmann et al., 2015). This finding also coincided with Fernandez (2002), who found that $76 \%$ of his sample consulted their parents when considering the purchase of a product.

The findings of this study also support Moschis and Churchill's (1978) theoretical propositions. According to the theoretical framework, parents play the most significant role as a financial socialization agent and keep influencing financial decisions during a lifetime (Gudmunson \& Danes, 2011; Moschis \& Churchill, 1978). These findings came as no surprise for two main reasons. First, most of the researchers examined in the literature review agreed in the active role that parents play, mostly during the early stages of childhood. These results might suggest that, as other ethnic groups in previous studies, the strong impact of parental socialization results from interactions between parents and their children during the early stages of childhood. Second, Puerto Ricans give great importance to keeping close family relationships, having parents, grandparents, or other guardians at the center of the family nucleus (Mogro-Wilson, Rojas, \& Haynes, 2016).

\section{Limitations of the Study}

The most notable limitations of this study relate to the size of the sample and its lack of representativeness. First, in a population of 216,742 college students registered in the fall of 2017, 198 respondents represent around $0.09 \%$ of the population. A larger sample would provide stronger, more reliable data to assess the population. Second, we used college students as a representative of the Puerto Rican population. However, we cannot assume that college students have the same financial experiences as all Puerto Ricans on the island. The third limitation of the study was its cross-sectional design, disregarding the advantages of longitudinal designs, experimental approaches, and qualitative research models. As expected, the cross-sectional design did not allow the manipulation of the independent variables. Thus, we were not able to make before and after comparisons of the collected data. Finally, the research team collected the data in Puerto Rico. Therefore, the outcomes of this study may not represent the financial socialization experiences of Puerto Ricans living in other countries, including the United States.

\section{Implications}

As confirmed in this study, children depend on their parents to develop financial skills. Therefore, financial education should focus on strengthening the financial skills of parents and adults. There is a limited offering in Puerto Rico for parents to develop financial skills. However, institutions of higher education, nonprofits, financial institutions, and the government may unify their efforts and resources to provide financial education to Puerto Ricans. Different organizations in the United States started addressing the need for financial education among children and adults. As a result, 17 states have required high school students to attend courses in personal finance since 2014 (Council for Economic Education, 2016). Likewise, 20 states require high school students to take a course in 
economics, and five states require a stand-alone semester course in personal finance (Council for Economic Education, 2016). The outcomes of this and previous studies performed in Puerto Rico provide plenty of reasons to create and implement new financial literacy programs in an effort to improve the financial wellbeing of Puerto Ricans.

\section{Recommendations for Future Research}

There are several generations of mainland American citizens that can trace their family ancestry to Puerto Rico. Life experiences in a foreign land transform and separate the social processes and communication habits of island and mainland Puerto Ricans. For this reason, future researchers in this area should replicate this study by collecting data from Puerto Ricans born in the mainland. Further studies would generate data that will promote the comparison, contrasting, and further understanding of socialization practices among Puerto Ricans.

\section{Final Summary}

The outcomes of this study highlighted how participants preferred to interact with parents to obtain financial knowledge. These findings agree with the theoretical framework of this study and with many researchers reviewed in the literature. However, parents did not appear as an effective source of information among respondents. In general, study participants failed the financial knowledge component of the survey, getting an average score of $39 \%$. This study brings an opportunity to continue the discussion of financial literacy levels among Puerto Ricans. However, this study did not fully clarify the social learning processes that Puerto Ricans employ to acquire and transmit financial knowledge and behaviors. The identification of information sources is only the first step into bigger, deeper, and broader research studies to understand island Puerto Ricans as a group. Studying the socialization experiences of Puerto Ricans from historical, social, and cultural outlooks may lead to a kaleidoscopic view of the complex processes that separate Puerto Ricans from other ethnic groups.

\section{References}

Ahluwalia, A. K., \& Sanan, P. (2016). Consumer awareness and consumer activism among adolescents: A socialization perspective. IUP Journal of Marketing Management, 15, 49.

Atkinson, L., Nelson, M. R., \& Rademacher, M. A. (2015). A humanistic approach to understanding child consumer socialization in U.S. homes. Journal of Children and Media, 9, 95-112. https://doi.org/10.1080/17482798.2015.997106

Bucciol, A., \& Veronesi, M. (2014). Teaching children to save: What is the best strategy for lifetime savings? Journal of Economic Psychology, 45, 451-

417. https://doi.org/10.1016/j.joep.2014.07.003

Castro-Gonzalez, K. C. (2014). Financial literacy and retirement planning: Evidence from Puerto Rico. Global Journal of Business Research, 8, 87-98.

Chowa, G., \& Despard, M. (2014). The influence of parental financial socialization on youth's financial behavior: Evidence from Ghana. Journal of Family and Economic Issues, 35, 376389. https://doi.org/10.1007/s10834-013-9377-9

Chu, S., \& Sung, Y. (2015). Using a consumer socialization framework to understand electronic wordof-mouth (eWOM) group membership among brand followers on Twitter. Electronic 
Commerce Research and Applications, 14, 251-260.

https://doi.org/10.1016/j.elerap.2015.04.002

Cole, S., Paulson, A., \& Shastry, G. K. (2016). High school curriculum and financial outcomes: The impact of mandated personal finance and mathematics courses. The Journal of Human Resources, 51, 656-698. https://doi.org/10.3368/jhr.51.3.0113-5410R1

Council for Economic Education. (2016). Survey of the states: Economic and personal finance education in our nation's schools. Retrieved from http://councilforeconed.org/

Delfino, A., Marengo, L., \& Ploner, M. (2016). I did it your way. An experimental investigation of peer effects in investment choices. Journal of Economic Psychology, 54, 113-123. https://doi.org/10.1016/j.joep.2016.03.005

Drever, A. I., Odders-White, E., Kalish, C. W., Else-Quest, N. M., Hoagland, E. M., \& Nelms, E. N. (2015). Foundations of financial well-being: Insights into the role of executive function, financial socialization, and experience-based learning in childhood and youth. The Journal of Consumer Affairs, 49, 13-38. https://doi.org/10.1111/joca.12068

Dündar, Ş. (2017). The effects of conscious consumerism-related parental role modeling, parental communication, and social studies on children's socialization as conscious consumers. Mersin University Journal of the Faculty of Education, 13, 726. https://doi.org/10.17860/mersinefd.316607

Erner, C., Goedde-Menke, M., \& Oberste, M. (2016). Financial literacy of high school students: Evidence from Germany. The Journal of Economic Education, 47, 95-105. https://doi.org/10.1080/00220485.2016.1146102

Fernandez, E. J. (2002). The consumer attitudes and behavioral patterns of generation Y in Puerto Rico: A picture of Puerto Rican teenage consumers (Doctoral dissertation). ProQuest Dissertations and Theses Global. (Order No. 3036289). Retrieved from https://searchproquest-com.ezp.waldenulibrary.org/docview/305430509? accountid=14872

Field, A. (2013). Discovering statistics using IBM SPSS Statistics. London, United Kingdom: Sage.

González-Corzo, M. A. (2015). Strategies to increase financial asset ownership among U.S. Hispanics. Journal of Financial Planning, 28, 52-61. Retrieved from https://www.onefpa.org/journal/Pages/default.aspx

Grohmann, A., Kouwenberg, R., \& Menkhoff, L. (2015). Childhood roots of financial literacy. Journal of Economic Psychology, 51, 114-133. https://doi.org/10.1016/j.joep.2015.09.002

Grohmann, A., \& Menkhoff, L. (2015). School, parents, and financial literacy shape future financial behavior. DIW Economic Bulletin, 5, 407-412. Retrieved from https://www.diw.de/de

Gudmunson, C. G., \& Danes, S. M. (2011). Family financial socialization: Theory and critical review. Journal of Family and Economic Issues, 32, 644-667. https://doi.org/10.1007/s10834$\underline{011-9275-\mathrm{y}}$

Hensley, B. J. (2015). Enhancing links between research and practice to improve consumer financial education and well-being. Financial Counseling and Planning, 26, 94-101. https://doi.org/10.1891/1052-3073.26.1.94

Hira, T. K., Sabri, M. F., \& Loibl, C. (2013). Financial socialization's impact on investment orientation and household net worth. International Journal of Consumer Studies, 37, 29-35. Retrieved from https://onlinelibrary.wiley.com/journal/14706431 https://doi.org/10.1111/ijcs.12003 
Huston, S. J. (2015). Using a financial health model to provide context for financial literacy education research: A commentary. Financial Counseling and Planning, 26, 102104. https://doi.org/10.1891/1052-3073.26.1.102

Jorgensen, B. L. (2007). Financial literacy of college students: Parental and peer influences (Master's thesis). Blacksburg, VA: Virginia Polytechnic Institute and State University. Retrieved from http://scholar.lib.vt.edu/theses/available/etd-10162007-143627/

Lusardi, A. (2015). Financial literacy skills for the 21st century: Evidence from PISA. The Journal of Consumer Affairs, 49, 639-659. https://doi.org/10.1111/joca.12099

Martínez, G. R. (2013). El conocimiento sobre planificación y manejo de las finanzas personales en los estudiantes universitarios [The knowledge about financial planning and personal finance management in university students]. Global Conference on Business \& Finance Proceedings, 8, 1350-1354. Retrieved from http://www.theibfr.com/

Mogro-Wilson, C., Rojas, R., \& Haynes, J. (2016). A cultural understanding of the parenting practices of Puerto Rican fathers. Social Work Research, 40, 237-248. https://doi.org/10.1093/swr/svw019

Moschis, G. P., \& Churchill, G. A., Jr. (1978). Consumer socialization: A theoretical and empirical analysis. Journal of Marketing Research, 15, 599609. https://doi.org/10.1177/002224377801500409

Muralidharan, S., \& Men, L. R. (2015). How peer communication and engagement motivations influence social media shopping behavior: Evidence from China and the United States. Cyberpsychology, Behavior, and Social Networking, 18, 595601. https://doi.org/10.1089/cyber.2015.0190

Puerto Rico Council on Education. (2018). Compendio Estadístico de la Educación Superior en Puerto Rico 2017-2018 [Statistical summary of higher education in Puerto Rico 2017-2018]. Retrieved from http://www.agencias.pr.gov/agencias/cepr/inicio/Pages/default.aspx

Shim, S., Serido, J., Tang, C., \& Card, N. (2015). Socialization processes and pathways to healthy financial development for emerging young adults. Journal of Applied Developmental Psychology, 38, 29-38. https://doi.org/10.1016/j.appdev.2015.01.002

Thaichon, P., \& Quach, T. N. (2016). Online marketing communications and childhood's intention to consume unhealthy food. Australasian Marketing Journal, 24, 79-86. https://doi.org/10.1016/j.ausmj.2016.01.007

Ward, S. (1974). Consumer socialization. Journal of Consumer Research, 1, 1-14. https://doi.org/10.1086/208584

The Journal of Social Change, sponsored by Walden University, welcomes manuscripts focusing on interdisciplinary research in social change that improves the human condition and moves people, groups, organizations, cultures, and society toward a more positive future.

Walden University Publishing: http://www.publishing.waldenu.edu 